\title{
Complex Mineral Fertilizers: \\ Opportunities of Manufacturing them from Technogenic Wastes
}

\section{UYLESBEK BESTEREKOV, KULYANDA KULBOSYNOVNA NURASHEVA*, ULZHALGAS BAHYTKYZY NAZARBEK, SAULE PULATOVNA NAZARBEKOVA and AYDAR ALIBEKOVICH BOLYSBEK}

48a Madeli Kozha Street, Apt. 67, Shymkent, X09D9A2 (160000), Kazakhstan.

*Corresponding author E-mail: nurasheva@mail.ru

http://dx.doi.org/10.13005/ojc/330110

(Received: December 01, 2016; Accepted: October 02, 2016)

\begin{abstract}
Purpose of the research is to study the development of technological modes of producing nitrogen-phosphorus-containing mineral fertilizer from industrial wastes in experimental conditions. Granulometric and substantial composition of phosphorus sludge and cottrell dust, mineralogical composition and microstructure of industrial waste for mineral fertilizers production have been studied. It was found possible to produce qualitative ammophos from phosphorus sludge and cottrell dust in proportion $2 / 1$, using decomposition by mixture of $30 \%$ aqueous solution ammonium sulfate and humic acid. Conducted experiments allow to design the technology for producing complex fertilizers. Harmful environmental impact of waste is lowered, also production costs of the new fertilizer are much lower than of the existing ones. Unlike the traditional method of ammophos production from phosphoric acid and ammonia, the offered method allows to produce the complex and assimilable fertilizer, containing phosphorus and nitrogen in optimum proportions.
\end{abstract}

Keywords: Technogenic waste, Phosphorus, Nitrogen fertilizers, Ammoniation.

\section{INTRODUCTION}

Development of industry all over the world has made the problem of complex processing of technogenic industrial wastes and involving nonstandard mineral resources in the production to be topical. Phosphorus production, widely demanded both in Kazakhstan and abroad, is an example.
Its production is determined by formation of large technogenic wastes in the form of overburden rocks, slag, phosphogypsum, ferrophosphorus, phosphorus sludge and cottrell dust. Only in Zhambyl oblast there have been piled up over 30 million tons of the above said wastes ${ }^{1}$. At the International Congress on issues of mineral resources and metallurgy industry (Astana, January 2014) Nursultan Nazarbayev, 
President of Kazakhstan said that in the country there have been piled up over 30 billion tons of techno genic wastes, the significant part of them is toxical. He emphasized, that now techno genic wastes should be considered as a self-sufficient raw materials base ${ }^{2}$. Today as a result of reductive electric melting of phosphate raw material only at Novo-Zhambyl phosphorus factory about 140$160 \mathrm{~kg}$ of cottrell dust are formed per one ton of manufactured yellow phosphorus. This cottrell dust in the form of suspension - cottrell milk is discharged into evaporation basins ${ }^{3}$. In addition to, on the territory of the former phosphorus factory in Shymkent there have been accumulated over 500 thousand tons of phosphorus sludge, the chemical and granulometric composition of which is characterized by complex inclusions of mineral components of charge and products of processing ${ }^{4}$.

Research of scientists and manufacturers and laboratory analyses as well show, that these technogenic wastes are quite valuable recoverable resources for production of composite building materials ${ }^{1,5}$, phosphorus and compound mixed fertilizers, containing phosphorus-potassium. Ways and technologies of production of ameliorant of potassic ammophos gypsum, superphosphate, double superphosphate, carbamide-ammonia fertilizer (CAF), monoammonium phosphate (MAPh), ammophos on the basis of phosphoruscontaining technogenic wastes are known ${ }^{3,6,7}$. Modes of production are worked out and the main characteristics of final output are determined. Alongside with that, today there are no completely founded technologies of processing phosphoruscontaining wastes into demanded products, containing nitrogen, phosphorus, potassium. The problem of complex recovery of wastes is not being solved. The offered technologies are imperfect, this explains the existence of non-decreasing volume of wastes. Therefore, all the known technological solutions did not find full-scale practical application. Thereupon, search of new possibilities of utilization of large-scale phosphor-containing recoverable raw material is still crucial.

\section{Methods of research}

In order to do laboratory research to determine physical and chemical features of production of complex fertilizer, containing phosphorus and nitrogen, the selection of phosphorus sludge has been taken carried out from different levels sludge collectors of LLP «Kainar» (Shymkent city). The cottrell dust is taken from collectors of cottrell milk of Novo-Zhambylskyi phosphorus factory (Taraz city). These selected samples were dried out at the temperature of $60-80^{\circ} \mathrm{C}$ and screened through a shaking sieve in accordance with State Standard (GOST) 21560-82 «Mineral fertilizers». Granulometric composition was determined using the shaking sieve screen "Analizette 3 ". Substantial composition of phosphorus sludge and cottrell dust were determined by chemical method according to GOSTs ${ }^{8}$. Mineralogical composition and microstructure of samples of phosphorus sludge and cottrell dust have been studied using Scanning Electronic Microscopy SEM JEOL of brand JSM6490 LV. It is worth to notice, that chemical and roentgen diffractometric analyses of samples of technogenic wastes in LLP «Kazphosphat» have been carried out repeatedly ${ }^{1,9}$. In these experimental conditions the mixture of phosphorus sludge and cottrell dust, taken in mass ratio 2:1, was subjected to decomposition in acid environment, formed from water solution of ammonia sulphate and humic acid. Duration of the decomposition process was 60 minutes at the temperature of $60^{\circ} \mathrm{C}$.

\section{Statistics of production and of mineral fertilizer consumption}

Elimination of negative impacts of natural risks, preservation of soil fertility, cropping capacity of agricultural crops to a large extent depends on usage of mineral fertilizers. Taking into account this fact Kazakhstan has adopted measures that stimulate the agricultural sector; also state support for expansion of fields of prior agricultural crops, growth of their productivity and improvement of their seed grain is provided for. The program «Agrobusiness -2020 " is being carried out at present, growth of export potential of agricultural sector to countries of Eurasian Economic Union (EEU) was the result of this program. With that mineral fertilizers are introduced only on $5 \%$ of cultivated areas (3 kg per hectare $)^{10,11}$. In Russia about $38 \mathrm{~kg}$ per 1 hectare of cultivated land are used, whereas in Europe and the USA the analogous figure is $130-140 \mathrm{~kg}^{12}$. Low level of using mineral fertilizers is connected with the fact, that in spite of state subsidization of this branch, peasant farms and farm enterprises cannot buy them 
in full. The thing is, that initially the subsidization program was planned irrationally. The agrarian can get $50 \%$ of subsidies for local and $30 \%$ for import fertilizers only after the purchase of necessary products $^{13}$. There are also many complications and bureaucratic longstops in getting subsidies. Poor competitiveness of produced fertilizers, their high transportation costs make the agricultural complex products not competitive.

At sufficiency of mineral resources the production of fertilizers is characterized by a poor level of development. At present in Kazakhstan only two factories operate, they are: LLP «Kazphosphat» (Taraz city) and «KazAzot» (Aktau city). The volume of nitrogenous fertilizer consumption in the internal market is estimated as 329 thousand tons per year. In 2014 import of this production to Kazakhstan was 166 thousand tons, i.e. half of the country's demand ${ }^{14}$. Level of ammonium saltpeter consumption in Kazakhstan is $\$ 50 /$ hectare, whereas in neighboring Russia it is $\$ 150 /$ hectare, in Germany it is about $\$ 200 /$ hectare $^{15}$.

It is foreseen to increase capacities of production of ammonia and nitrogen fertilizers up to 400 thousand tons per year by 2018 . More than $\$ 160$ million will be invested. Modernization of LLP «KazAzot» will allow to increase the production competitiveness, because the production cost of nitrate fertilizer will decrease by 35 per cent- $\$ 140$ per ton, labor productivity will grow four times - $\$ 45$ thousand. $40 \%$ of fertilizers are supposed to be exported, including the deliveries into the EEU countries ${ }^{14}$. Factory of mineral fertilizers LLP "Kazphosphat" produces a wide range of phosphatic fertilizers ${ }^{16}$ :

- $\quad$ Ammophos (mixture di-, monoammonium phosphate) - 46\% $\mathrm{P}_{2} \mathrm{O}_{5}, 10 \% \mathrm{~N}$;

- $\quad$ Ordinary superphosphate - $19 \% \mathrm{P}_{2} \mathrm{O}_{5}$;

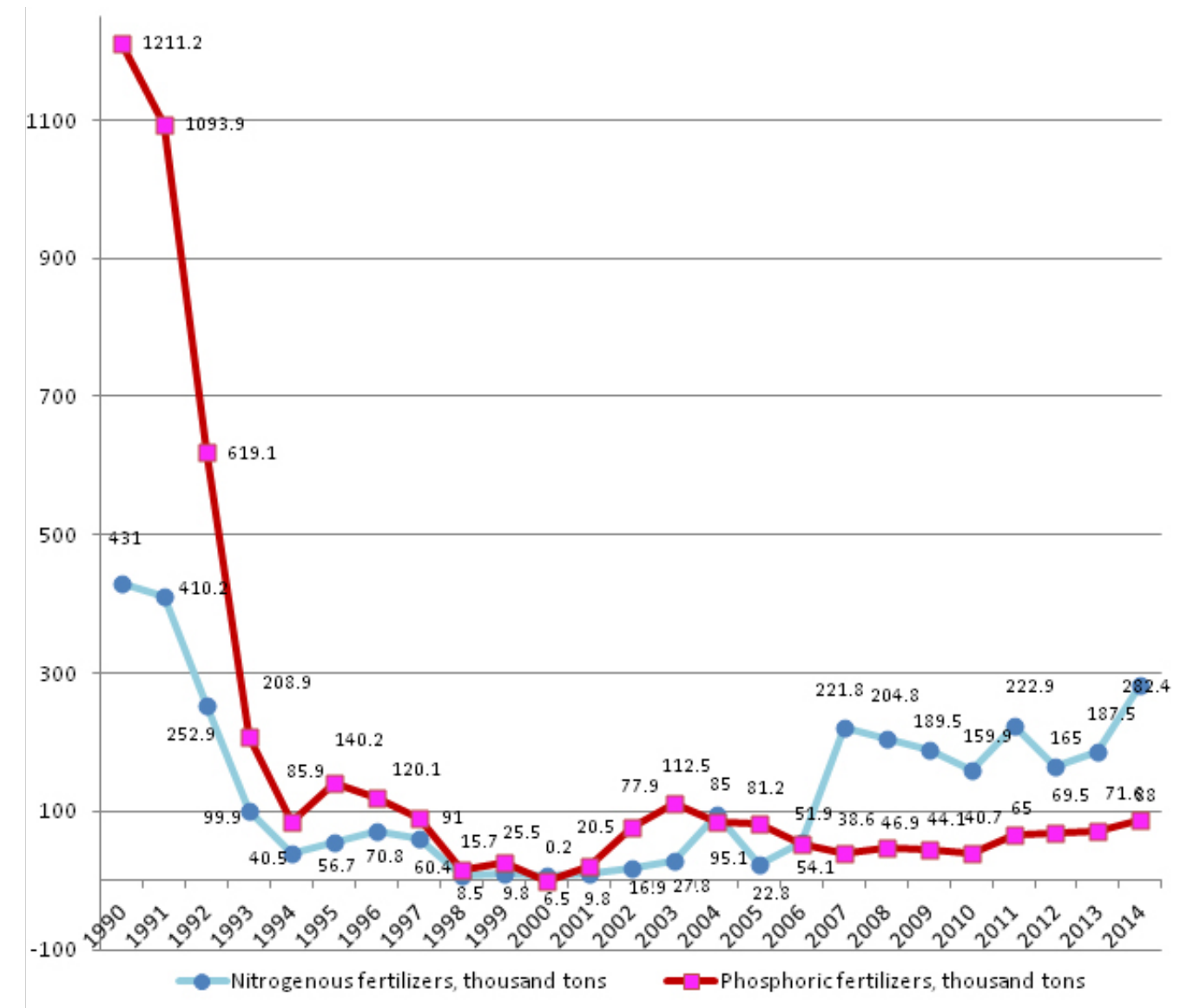

Fig. 1: Production of mineral fertilizers in Kazakhstan 


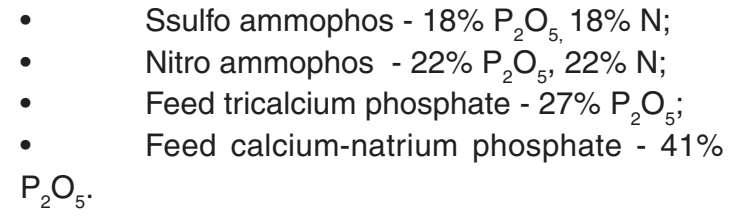

The output is realized in China, Ukraine, Belarus, Tadjikistan ${ }^{16}$. A large work in development of phosphoric fertilizers market of Afghanistan, Kyrgyzstan, Romania, Czechia, Bulgaria, Iran is being carried out. Construction of a new plant for production of phosphorus, nitrogenious and complex fertilizers has started in Kazakhstan. This factory with capacity of about 1 million tons per year will be based on the deposit Kok-Zhon in Zhambyl oblast ${ }^{10}$. It will provide $100 \%$ of Kazakhstan internal market. Surplus of products is intended for export. Capacity of the factory is much greater, than the demand of Kazakhstan market. In 2018 it is expected that the factory will function at its full production capacity. The planned investments are approximately 2 billion dollars ${ }^{10}$.

Construction of a factory of potash fertilizers will be started in Aktobe oblast. China invests 3,8 billion dollars in this project ${ }^{17}$. Chinese companies have offered to increase the production from one million tons up to seven million tons per year in 2025 taking into account the export of surpluses. It should be noted, that practically all the countries export part of manufactured mineral fertilizers: phosphorus ones $-35-50 \%$ of the world production, potassium $-80 \%$, nitrogen $-25-40 \%{ }^{18}$. In 2014 about 47 million tons of fertilizers were produced in the world, in terms of $100 \%$ of nutrients. Today the first-rate producers of mineral fertilizers are: China, which controls $21 \%$ of the market, the USA (13\%), India (10\%), Russia $(8 \%)$ and Canada (8\%). In west Europe $80 \%$ of

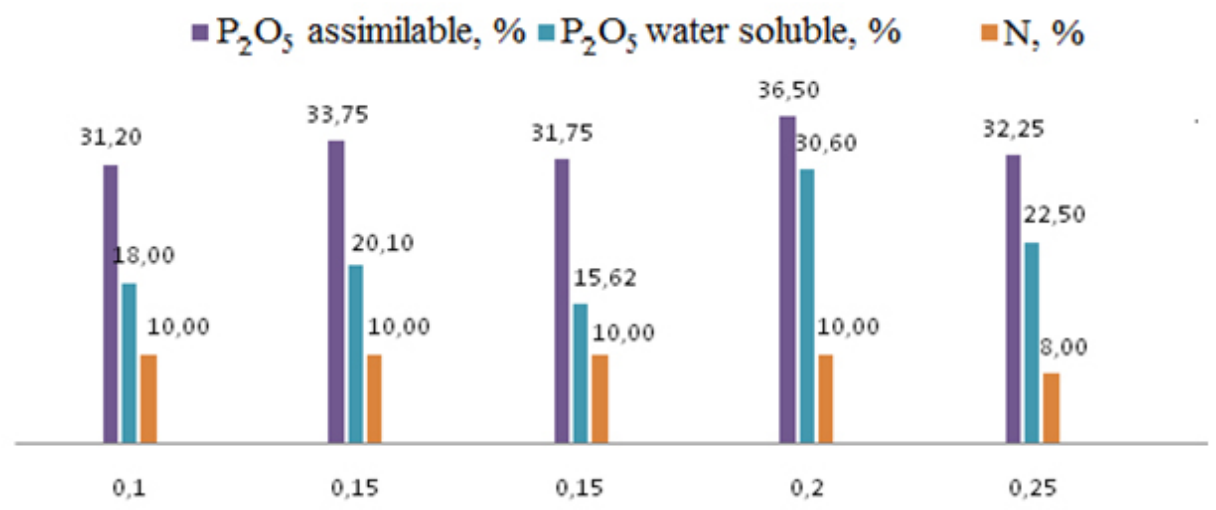

Fig. 2: Dependence of content of assimilable $\mathrm{P}_{2} \mathrm{O}_{5}$ and water-soluble $\mathrm{P}_{2} \mathrm{O}_{5}$, nitrogen (in \%) in final product from specific discharge of humic acid, I/kg
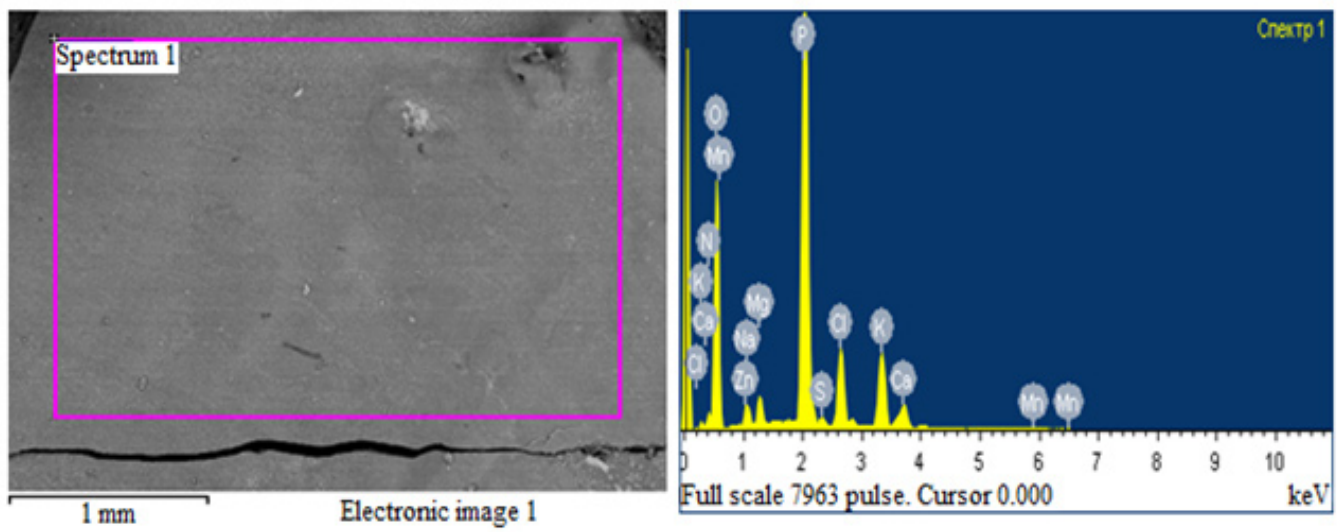

Fig. 3: Microscopic picture of complex mineral fertilizer 


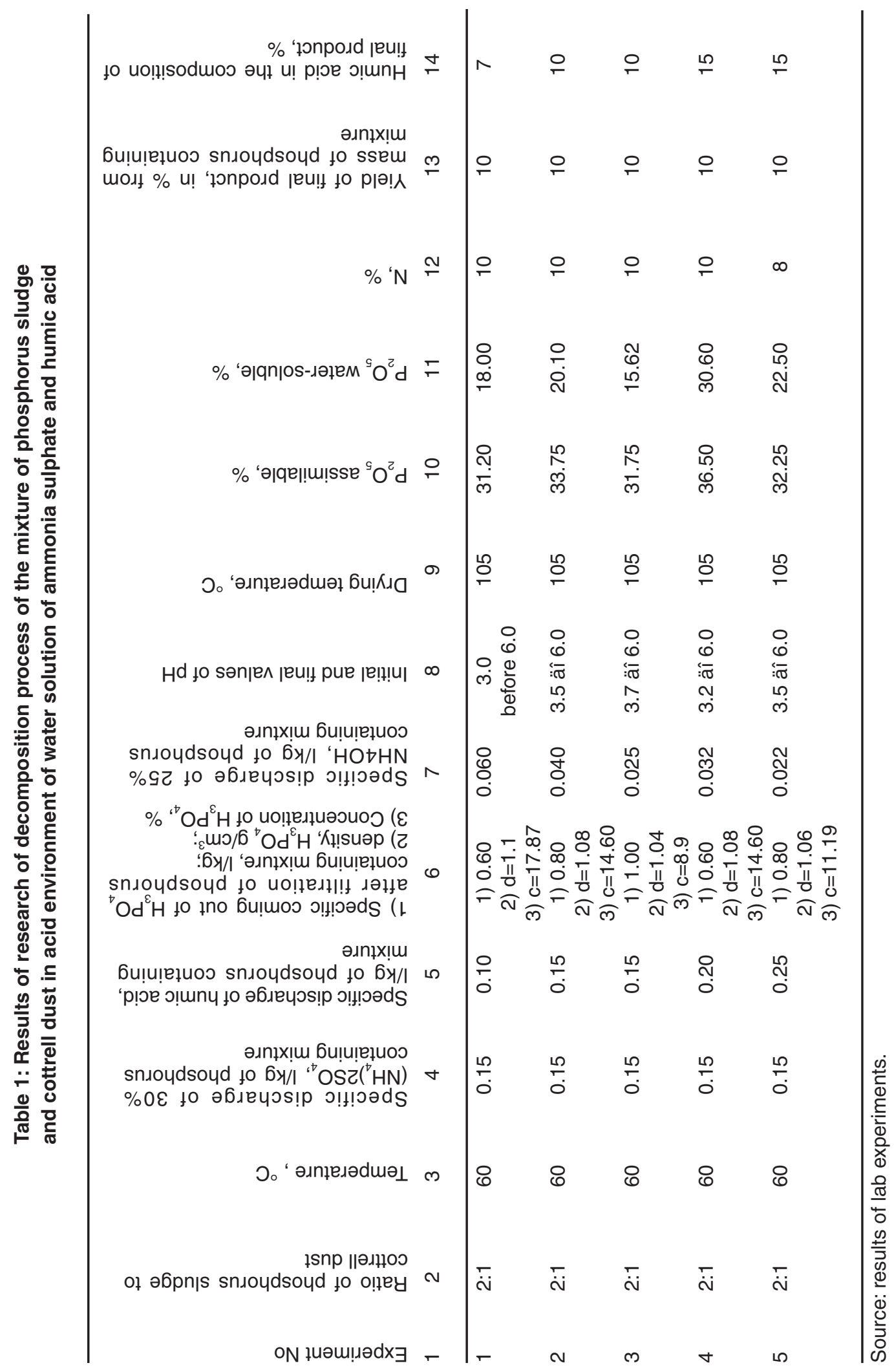


total production of fertilizers are controlled by 8 large companies, in the USA $60 \%$ of nitrogenous fertilizers are provided by 5 companies. The last years the influence of the USA in the world market of fertilizers goes down. Since 2006 high rates of growth are presented by the markets of South East Asia and Latin America ${ }^{18}$.

In Kazakhstan production of mineral fertilizers does not In Kazakhstan the production of mineral fertilizers does not have a clear dynamics of growth (figure 1) ${ }^{19,20}$. Before collapse of the USSR this sector of production worked for internal consumption, later it stopped to be demanded inside the country, volumes of consumption of fertilizes decreased several tens of times. Therefore, the sector was forced to reorient for export. Some increase of volumes was reached in producing ammonia, nitrogenous fertilizers after 2007; however, the capacities were not restored. The last years the volumes of fertilizers' export are approximately 220-250 thousand tons. Import of fertilizers in Kazakhstan in 2014 was 246.8 thousand tons at the sum of 84161 thousand dollars. The exported fertilizers are: ammonium, sodium tripolyphosphate, other fertilizers, containing two nutrients - nitrogen and phosphorus. Imported goods are: herbicides, phytohormones, chemical remedies for plant protection. $98 \%$ of imported phosphorus fertilizers are brought from Uzbekistan ${ }^{21}$. Agricultural formations of various patterns of ownership (in Kazakhstan there are more than 200 thousand formations) cry out for complex fertilizers, containing nitrogen, phosphorus and potassium because of the dry climate and soil low fertility. The most demanded are: ammophos, which is a concentrated ballastless fertilizer with two nutrients in soluble form - nitrogen and phosphorus $^{22}$. The situation of phosphorus in farming in Kazakhstan is quite vital. Therefore, we would like to concentrate on conditions of manufacturing more effective phosphorus fertilizers.

\section{Discussion of the research results}

The widely demanded complex NP fertilizer: ammophos is characterized by content of the main component - monoammonium phosphate $\mathrm{NH}_{4} \mathrm{H}_{2} \mathrm{PO}_{4}$ with admixture (up to $10 \%$ ) of diammonium phosphate $\left(\mathrm{NH}_{4}\right)_{2} \mathrm{HPO}_{4}$. Production of ammosphos according to traditional technology anticipates decomposition of phosphates in conditions of wetprocess phosphoric acid abundance. From then on ammoniation by acidic phosphate suspension, its further boiling-down, granulating and dehydration of boiled down mass take place ${ }^{23}$.

Unlike the traditional method we used for production of ammophos the mixture of phosphorus sludge, cottrell dust, ammonia sulphate and humic

Table 2: Element-by-element composition of complex mineral fertilizer

\begin{tabular}{lccccccccccc}
\hline Element & $\mathbf{N}$ & $\mathbf{O}$ & $\mathbf{N a}$ & $\mathbf{M g}$ & $\mathbf{P}$ & $\mathbf{S}$ & $\mathbf{C l}$ & $\mathbf{K}$ & $\mathbf{C a}$ & $\mathbf{M n}$ & $\mathbf{Z n}$ \\
\hline Weight composition, \% & 11.68 & 48.81 & 1.92 & 1.60 & 23.38 & 0.61 & 3.84 & 5.84 & 1.84 & 0.18 & 0.27 \\
Weight composition, & 11.68 & - & 2.59 & 2.65 & 53.56 & 1.31 & - & 7.03 & 2.57 & 0.23 & 0.33 \\
in terms of oxides, \% & & & & & & & & & & & \\
\hline
\end{tabular}
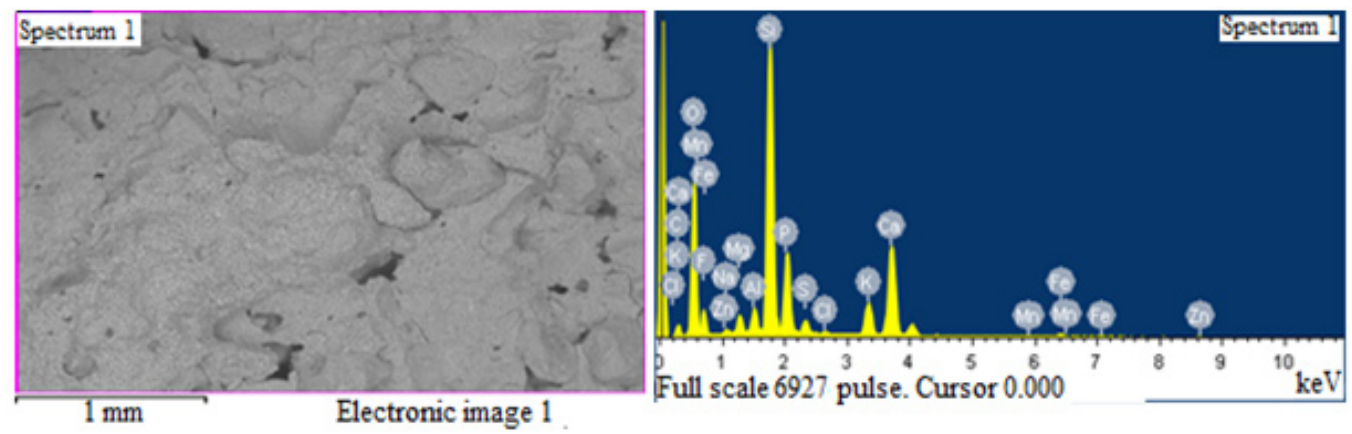

Fig. 4: Microscopic photo of dry residue, derived after filtration 
acid at their various ratios. At this ammonia sulphate was used to increase nitrogenous component in the composition of produced ammophos; the humic acid with $ð \mathbf{l}=0.760$ was used as a substitute of sulphuric, nitric or phosphoric acids. Phosphorous sludge was selected from different levels of sludge collectors of LLP «Kainar», and cottrell dust was taken from the collectors of Novo-Dzhambyl phosphorus factory. It is found, that the substantial composition of phosphorus sludge and cottrell dust correspond to the following content:

- In the composition of phosphorus sludge, \%: $\mathrm{P}_{2} \mathrm{O}_{5}$ total - 17.01, $\mathrm{K}_{2} \mathrm{O}-6.72, \mathrm{Na}_{2} \mathrm{O}-0.41$, $\mathrm{SiO}_{2}$ - 45.38, $\mathrm{CaO}$ - 13.74, $\mathrm{MgO}-4.16, \mathrm{Al}_{2} \mathrm{O}_{3}$ - 1.08, $\mathrm{Fe}_{2} \mathrm{O}_{3}-0.81, \mathrm{C}-5.91, \mathrm{~S}-0.40$;

- In the composition of cottrell dust, \%: $\mathrm{P}_{2} \mathrm{O}_{5}$ total. - 23.05, $\mathrm{K}_{2} \mathrm{O}-7.05, \mathrm{Na}_{2} \mathrm{O}-0.55, \mathrm{SiO}_{2}$ -25.08, $\mathrm{CaO}$ - 8.99, $\mathrm{MgO}-1.29, \mathrm{Al}_{2} \mathrm{O}_{3}-2.66$, $\tilde{N}-22.34, \mathrm{~S}-0.36$.

The results, obtained on SEM, showed, that minerals - calcium silicates, diopside and potassium aluminum silicates with inclusion of phosphate compounds of calcium prevail in phosphorus sludge and cottrell dust ${ }^{22}$. Chemical aspect of the decomposition process of the mixture of phosphorus sludge and cottrell dust in acid environment of water mixture of ammonia sulphate and monohydric humic acid can be described by the following equation:

$$
\begin{aligned}
& \quad \mathrm{Ca}_{5}\left(\mathrm{PO}_{4}\right)_{3} \mathrm{~F}+\text { 8humic acid }+2\left(\mathrm{NH}_{4}\right) \\
& \mathrm{SO}_{4}==2 \mathrm{CaSO}_{4}+4 \mathrm{NH}_{4}(\text { humate })+\mathrm{H}_{3} \mathrm{PO}_{4}+ \\
& 2 \tilde{N a ̀} \text { (humate })_{2}+\mathrm{Ca}\left(\mathrm{H}_{2} \mathrm{PO}_{4}\right)_{2}+\mathrm{HF}
\end{aligned}
$$

Table 4: Basic indices of dry residue, derived after filtration

\begin{tabular}{llc}
\hline No & Indices of dry residue & Value \\
& & \\
\hline 1 & $\mathrm{P}_{2} \mathrm{O}_{5}$ assimilable, \% & 13.25 \\
2 & $\mathrm{P}_{2} \mathrm{O}_{5}$ water-soluble, \% & 4.75 \\
3 & $\mathrm{~N}, \%$ & 4.75 \\
4 & Yield of final product, & 0.85 \\
& kg/kg of initial phosphorus & \\
& containing mixture & \\
5 & Strength of granules, kglcm ${ }^{2}$ & 3.40 \\
6 & Humic acid, \% & $7-10$ \\
7 & pH & 5.20 \\
& & \\
\hline
\end{tabular}




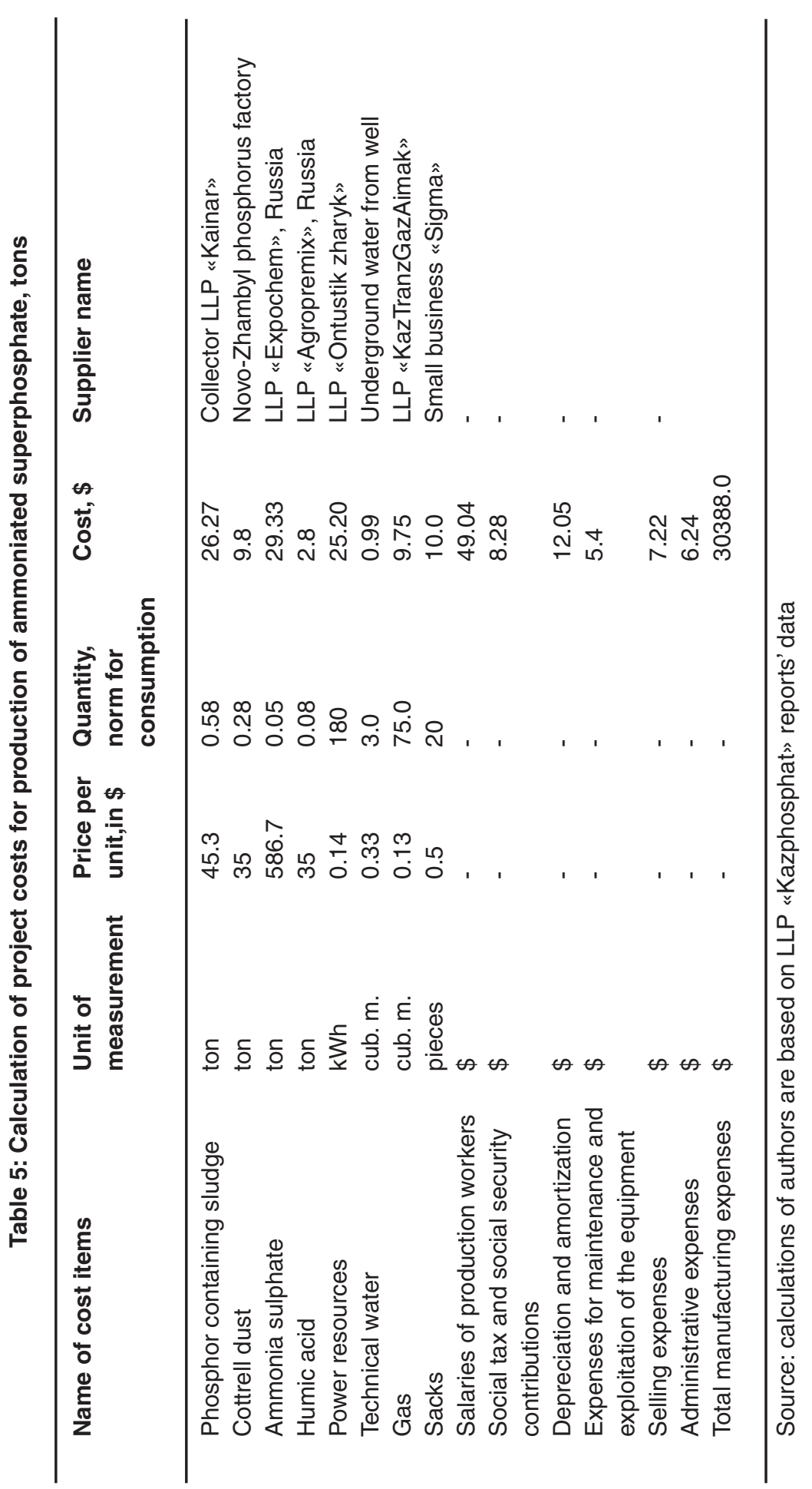


After decomposition the mixture was subjected to filtration. It has been found that the obtained liquid phase - the filtrate has density of 1.08 and ðI $=3.5$. This gives evidence, that the filtrate is a phosphoric acid with the concentration of $14.60 \%$. The derived phosphoric acid was ammoniated by $25 \%$ gas-liquor up to $\mathrm{pH}=6.0$. The process of neutralization of phosphoric acid by gas-liquor can be described by known reactions of the following types:

$$
\begin{aligned}
& \mathrm{H}_{3} \mathrm{PO}_{4 \text { (iquid) }}+\mathrm{NH}_{4} \mathrm{OH} \text { (liquid) }=\mathrm{NH}_{4} \mathrm{H}_{2} \mathrm{PO}_{4 \text { (crystal) }}+\mathrm{H}_{2} \mathrm{O}
\end{aligned}
$$

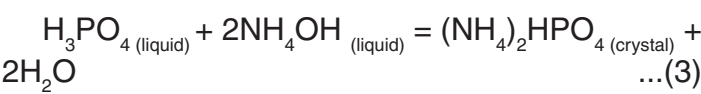

The process of ammonization of filtrate phosphoric acid by gas-liquor was carried out till reaching the final $\mathrm{pH}=6.0$. The derived neutralized solution was subjected to drying in the drying cabinet at temperature $105^{\circ} \mathrm{C}$ up to complete crystallization of the mixture of monoammonium phosphate and diammonium phosphate. As the result of drying white powder with high solvability in water was derived. The derived product is being analyzed for content of assimilable and water-soluble $\mathrm{P}_{2} \mathrm{O}_{5}$, ammonia and nitrogen. The accepted ratio of phosphorus sludge to cottrell dust, the temperature mode of the process of their decomposition in acid environment, expendable indices of $30 \%$ solution of ammonia sulphate and humic acid are presented in table 1 . The conditions of carrying out the process of ammoniation and the characteristic of the final product are also presented here. Analysis of the results of table 1 shows, that the largest indices on assimilable $\bigoplus_{2} \hat{\imath}_{5}$ and water-soluble $\bigoplus_{2} \hat{I}_{5}$ at maximum amount of nitrogen in the final product can be observed in experiment 4 . Thereat, as it seen in figure 2, the maximum amount of assimilable $\bigoplus_{2} \hat{l}_{5}$ and water-soluble $\bigoplus_{2} \hat{I}_{5}$ and nitrogen in the final product is observed at specific discharge of 0.20 liter of humic acid per one kilogram of the mixture of phosphorus sludge and cottrell dust.

Physical and chemical features of complex mineral fertilizer, containing nitrogen-phosphor, and which was produced on the basis of phosphorus sludge and cottrell dust were studied. Elementby-element and mineralogical analyses of its composition were done using SEM. The results of microscopic studies ${ }^{24}$, gave opportunity to get the surface image of the studied samples and spectra of isolated points with presentation of element-byelement and percentage composition, and also diffraction maxima of separate elements with high three-dimensional resolution and required depth of vision field. The microscopic picture and results of element-by-element analysis of the complex mineral fertilizer are presented in figure 3 and table 2.

From figure 3 it follows, that the surface of the decomposed micro section is characterized by high ability to pass light. The results of element-byelement and weight analyses of complex mineral fertilizer (table 2) tell about the advantage of reality of processes' behavior of ammophos production according to the developed methods. As it is follows from table $2 \mathrm{P}_{2} \mathrm{O}_{5}$ compounds in complex with nitro compounds are the main constitutive minerals of the manufactured product. Also $\mathrm{K}_{2} \mathrm{O}$ (up to $7.03 \%$ ), $\mathrm{NaNO}_{3}$ (up to $2.59 \%$ ) and admixtures of magnesium sulfate and calcium within limits of $2.57-2.65 \%$ are present as impurity inclusions. The manufactured product according to the content of phosphoric anhydride (53.56\%) and nitrogen (11.68\%) corresponds to ammophos GOST $18918-85$ of grade À with zinc admixtures ${ }^{8}$. The analysis of data of table 3 and figure 4 about element-by-element composition of dry residue, obtained after filtration, proves the presence of carbon in it $-12.73 \%$, of silicon $-16.18 \%$ (in terms of $\mathrm{SiO}_{2}-34.60 \%$ ), of fluorine $-5.30 \%$, of calcium $-8.73 \%$ (in terms of Ñâl - $12.21 \%$ ) and phosphorus $-5.81 \%$ (in terms of $\mathrm{P}_{2} \mathrm{O}_{5}-13.31 \%$ ).

Results of chemical analysis of dry residue (table 4) proves the presence of $\bigoplus_{2} \hat{I}_{5}$ assimilable $-13.25 \%, \bigoplus_{2} \hat{I}_{5}$ water-soluble- $4.75 \%$ and $\mathrm{N}-4.75 \%$, and also humic acid $7-10 \%$ in it. The above mentioned information allows us to view the possibility of using dry residue as ammoniated superphosphate. It is found, that this product is characterized by high solubility in water. So for example, its granules 5-8 $\mathrm{mm}$ in diameter dissolve in water within 3-5 seconds. Successful experiments allow to design the technology of production of the desirable product, meant for complete using sludge, cottrell dust and involvement of wastes.

Experiments show, that the problem of wastes is in imperfect technology, which causes them: 
mountains of phosphorus sludge, non-commercial ores, soil salinization, environmental contamination. The technology of utilization of phosphorus sludge and cottrell dust, offered by us, decreases harmful environmental impact. According to our calculations the production costs of a new fertilizer are much less than, than those ones according to the current scheme of ammophos production by about $19 \%{ }^{16}$. This has a big significance, when expensiveness of fertilizers does not allow the farm companies to buy them in sufficient amount. This leads to a significant drop of crops capacity. Approximate costs are being planned in the following amount (table 5). The developed way of new fertilizer production by means of wastes' utilization is recommended for introduction into the production process on the existing area of ammophos shop of the factory "Mineral fertilizers" of LLP «Kazphosphat».

\section{CONCLUSION}

The results of performed research allow to conclude the following:

- $\quad$ Production of marketable ammophos with content of assimilable phospholic anhydride $-53.56 \%$, nitrogen $-11.68 \%$, zinc $-0.33 \%$, and also humic acid $-10-15 \%$ is possible on the basis of mixture of phosphorus sludge and cottrell dust in ratio 2:1, using for their decomposition the $30 \%$ water solution of ammonia sulphate and humic acid, at temperature $60^{\circ} \mathrm{C}$ degrees and optimal duration of the process equal to 60 minutes; Dry residue, derived after the filtration stage has in its composition : phosphor $-5.81 \%$ (in terms of $\mathrm{P}_{2} \mathrm{O}_{5}-13.31 \%$, including $\mathrm{P}_{2} \mathrm{O}_{5}$ assimilable $-13.25 \%, \mathrm{P}_{2} \mathrm{O}_{5}$ water-soluble $-4.75 \%$ ), nitrogen $-4.75 \%$, humic acid $7-10 \%$, which corresponds to the composition of ammoniated superphosphatel;

- Initial humic acid, used in the process of decomposition of phosphatic secondary raw materials, is a highly effective substitute of expensive and aggressive mineral acids - sulphuric and nitric; humic acid in the composition of ammophos and ammoniated superphosphate will perform the role of organo-mineral additive,contributing to soil structure improvement; at the same time the humic acid will act as a plant protective composition against blasts and plant diseases.

\section{ACKNOWLEDGEMENT}

The research was conducted within the framework of budget financing. The authors express their gratitude to the leadership M.Auezov South Kazakhstan State University for the opportunity to carry out the research. The authors continue their research, work closely with the specialists of the company, which is a part of the chemical cluster of Taraz city (Kazakhstan).

\section{REFERENCES}

1. Beisekova, Ò.I.; Òurgumbayeva, H.H.; Lapshina, I.Z.; Shànbayev, İ.Zh.; Àbdualieva, Zh.U. "Utilization of technogenic wastes of phosphorus industry for production of building composites", Modern day problems of science and education. 2015, 2, 22-24, available at: http://www.science-education.ru/ ru/article/view?id=21680 (accessed 29 June 2016).

2. Baigarin, Ì. (2014), "There are no wastes there is incomplete production: it is necessary to stop accumulation of technogenic wastes in Kazakhstan" - interview of A. Begeneyev, the Deputy of Mazhilis of Parliament of Republic
Kazakhstan, published 13.01.2014, available at: http://www.inform.kz/rus/article/2620769 (accessed 29 June 2016).

3. Àldashov, B. À.; Sinyaeva, V. Ò. "Development of the innovated method for getting new complex high quality fertilizer - ameliorant of ammophos of potash plaster", Chemistry and chemical technology. Fundamental problems of creating new materials and technologies, 2010, 5, 6-9, Àlmaty, available at: http://www.rusnauka.com/34_NIEK _2010/Chimia/74795.doc.htm (accessed 30 June 2016).

4. Myrzakhmetova, B.; Besterekov, U.; 
Petropavlovski, I.; Ahnazarova, S.; Kiselev V.; Romanova S. "Optimization of Decomposition Process of Karatau Phosphorites". Eurasian ChemTech Journal. 2012, 14, 183-190.

5. Huang Yun; Lin Zong Shou "Investigation on phosphogypsum steel slags granulated blast furnace slags limestone cement", Construction and Building Materials, 2010, 24, 1296-1301.

6. Nazarbek, U.B.; Besterekov, U.; Petropavlovski, I.À.; Beisenbayev, Î.Ê.; Nazarbekova, S.P. «Bases of Technology and Optimal Regime Indicators of Acid Decomposition Process of Phosphorus Sludge" Oriental journal of Chemistry, 2015, 31(3), 1409-1416.

7. Batkayev, R.I. "Development of technology for manufacturing marketable production from technogenic wastes of phosphorus production. Synopsis of the thesis in candidacy for the degree of Doctor of Engineering". ì,.Àuezov South Kazakhstan State University, Shymkent. 2010.

8. Mineral fertilizers. Test methods, Collection of GOSTs. - Moscow: Publishing house of Standards, 2003, 346p.

9. Ourgumbayeva, I.Z. and others. "Problems of utilization of technogenic wastes of phosphorus industry of Zhambyl region of the Republic of Kazakhstan", Proceedings of International conference "Satpayev readings, devoted to the $80^{\text {th }}$ Anniversary of K.Satpayev KazNTU». Almaty, 2014,2, 557-562.

10. Dana Nurgali, (2013), "Gumus sapiens", published 27 February 2013, available at: http://expertonline.kz/a10306/ (accessed 2 July 2016).

11. Dana Nurgali, (2013), "Land capacity declines in Kazakhstan", published 27 February 2013, available at: http://24.kz/ ru/news/social/item/53817-v-kazakhstaneuvelichilos-proizvodstvo-mineralnykhudobrenij (accessed 26 June 2016).

12. Angelina Zhukova, "Chemical Dependence", Russian Business Paper. 2015, 32 (1011), available at: http://rg.ru/2015/08/18/ zavisimost.html (accessed 28 June 2016).

13. Rules of subsidization of fertilizers cost (except the organic ones). Government regulation of the Republic of Kazakhstan, No.574, dated 29 May 2014, Àstana, available at: http://agbz.ru/news/subsidii-naudobreniya-v-kazahstane (accessed 24 June 2016).

14. Kazakhstan plans to export up to 40 per cent of the produced volume of nitrogen fertilizers, published 26 December 2015, available at: http://tengrinews.kz/money/kazahstanplaniruet-otpravlyat-eksport-40-protsentov286364/ (accessed 4 July 2016).

15. Russian's economy, figures and facts, Part 9 "Chemical industry», published 2 July 2015, available at: http://utmagazine.ru/ posts/10562-ekonomika-rossii-cifry-i-faktychast-9-himicheskaya-promyshlennost (accessed 30 June 2016).

16. Official site of LLP "Kazphosphat" factory "Mineral fertilizers". Taraz city, available at: http://www.kazphosphate.kz/stru_podr/zmu/ (accessed 8 July 2016).

17. China is invests 3.8 billion dollars for fertilizers in Kazakhstan, Information Agency of Russia "TASS", published 14 December 2014, available at: http://www.ng.ru/news /488435. html (accessed 5 July 2016).

18. World market of mineral fertilizers (2015), Academy of the Environment of the Industrial Markets, available at: http:// www.newchemistry.ru/letter.php?n_id=2247 (accessed 4 July 2016).

19. Production of industrial products in the Republic of Kazakhstan 1990-2014, (2015), Sector $\tilde{N}$ «Manufacturing industry», Official site of the Committee on Statistics of Ministry of State's Economy, available at: http://stat. gov.kz/faces (accessed 7 July 2016).

20. Main figures per branches of industrial development and industry safety, Section "Chemical industry". Analytical note of Ministry on Innovations and Development of Kazakhstan. Àstana, 2015, p.32, available at: www.mid.gov.kz/.../osnovnye_pokazateli_ otrasley_mi (accessed 20 June 2016).

21. Market of fertilizers in Republic of Kazakhstan: production, manufacturers, volume of exports and import, forecast of development, Marketing reference book KazDATA, available at: http://kazdata.kz/04/2015-2014-12kazakhstan-production-udobreniya.html (accessed 7 July 2016).

22. Nazarbek, U.B.;Besterekov, U.; Petropavlovski, 
I.À.; Beisenbayev, Î.Ê.; Nazarbekova, S.P., , "Features of technogenic wastes microstructure of phosphorus production, applicable for obtaining compound fertilizers", Collection of scientific work "International Conference of Industrial Technologies and Engineering", Shymkent city, 2014, 5 - P.97104.
23. Board of Consultants \& Engineers NIIR Project Consultancy Services (NPCS). "The Complete Technology Book on Minerals \& Mineral Processing". Format: Paperback. Pages: 712. Publisher: Asia Pacific Business Press Inc. 2000.

24. Rid, S.J.B., (2008), "Electronic-microprobe analysis and scanning electron microscopy in geology", Moscow: Ed. «Technosphera», p. 232. 